\title{
Marine Environment and Climate Change: Legal Aspects of Protection and Prevention Against Coral Reef Degradation in Indonesia
}

\author{
Dina Sunyowati \\ Postgraduate School \\ Universitas Airlangga \\ Surabaya, Indonesia \\ dina@fh.unair.ac.id
}

\author{
Annisa Firdhausy \\ Faculty of Law \\ Universitas Airlangga \\ Surabaya, Indonesia \\ afirdhausy@gmail.com
}

\begin{abstract}
Coral reefs are one of the most important marine ecosystems, where fish and marine life breed. They also prevent coastal abrasion, and have economic value for the fishing industry, tourism and the environment. In the last ten years, there has been a crisis of coral reef damage due to the large number of irresponsible fishing activities that have become a trigger for global warming. Some of the symptoms that have begun to be seen around the world include rising sea levels, melting ice in the Arctic, changing storm directions and so on. Based on the data from the Indonesian Institute of Sciences (LIPI), it states that the condition of coral reefs in Indonesia has increased from year to year. Coral reefs in Indonesia have a damaged condition of around $25-35 \%$. Damage to coral reefs is a threat to human life, and also is a threat to marine life. Based on the results of the World Ocean Conference (WOC) in Manado 2009 embodied in the Coral Triangle Initiative (CTI), obligations were established for countries with undersea ecosystems with biological natural resources to seek to conserve the coral reefs. The efforts that have been made by the government are in the form of the arrangement of laws and regulations which are effective and have legal certainty. Following the CTI, Indonesia has established regulations on coral reef protection based on international conventions and other regulations. The regulations are made as an effort to prevent, manage and conserve the coral reefs. The research method used in this
\end{abstract}

paper was normative juridical, with a conceptual and statute approach.

Keywords: Coral Reefs; Climate Change; Conservation.

\section{INTRODUCTION}

\section{A. Background}

The need for the regulation of marine conservation has been triggered by concerns about the increasing number of activities in resource management in coastal and marine areas. Coral reefs are one of the important ecosystems involved in the sustainability of existing resources in coastal and marine areas, and as an archipelagic state, Indonesia has many coastal waters inhabited by coral reefs that have been damaged or degraded due to the lack of public and government attention to the sustainable management of coral reefs.[1]

Environmental degradation, especially the damage to coral reefs, has resulted in enormous losses in the environment and it takes a long time for it to recover so that coastal and marine areas can function optimally. The management of coral reef ecosystems in an integrated and sustainable way is still difficult to be realised because of the low awareness and participation of the community in conservation. The government has not optimally handled the issue of coastal and marine conservation area management in Indonesia. Based on the data from the Indonesian Institute of Sciences (LIPI), it states that the condition of the coral reefs in Indonesia has increased gradually from year to year. 
Due to awareness of the importance of coral reefs and their interrelationship with other biological resource conservation, countries around the world have designated around 100 Marine Protected Areas (MPAs) as the focus of marine conservation efforts aimed at biodiversity protection.[2] The World Ocean Conference (WOC) 2009 and Coral Triangle Initiative (CTI) 2009 states that climate change and global warming in the world today have tremendous potential for the existence and sustainability of coral reefs. The example of the changes we can see is the melting ice in the Arctic region resulting in rising sea levels and changes in storm patterns. Countries agree to conserve and protect the coral reef ecosystem in a sustainable and lawful manner.

\section{B. Research Purposes}

This article was created based on research for the following aims:

1. Do some research and analyse national regulations and international regulations which are related to conservation management, especially to do with the coral reef.

2. Reviewing the efforts that will and have been done for saving the marine resources in Indonesia, especially coral reefs, to reduce climate change.

\section{Research Methods}

This article was prepared by conducting prior research using two problem approaches, namely the conceptual approach and statute approach. The conceptual approach [3] is drawn from the concepts that developed in the science of international law, the law of the sea and environmental law. The statute approach [4] is an approach to review legislation, and the provision of international conventions, including international treaties related to the topics to be discussed.

\section{ANALYSIS}

\section{A. Condition of Coral Reefs in Indonesia and the World}

The coral reefs in Indonesia are estimated to have an area of $75.000 \mathrm{~km}^{2}$ which is about $12 \%$ to $15 \%$ of the world's coral reefs [5]. In the Indonesian ocean was found 362 species of Scleractinia (rock coral) (Romimohtarto, 2001). Indonesia is at the core of the distribution of the world's rock corals so this has made Indonesia became a tourist destination for coral reefs (Romimohtarto, 2001).[6]

In 2013, according to existing data, it states that almost $70 \%$ of coral reefs have been damaged. The latest data from the Research Center Oceanography Institute of Science Indonesia (LIPI) in this last year states there has been a great improvement, although there are still coral reefs in a state of disrepair[7]. Although the condition of coral reefs every year has gradually increased, in 2015 and 2016 there was a decrease caused by the rising sea temperature due to the El Nino weather anomaly. This leads to coral bleaching and is likely to occur frequently in the future.

Several years ago was the worst year for coral reefs around the world, due to the number of coral reefs damaged by pests or infectious diseases, fishing by fish bombs and other fishing gear, and the increasing temperature of the earth's temperature as well as water pollution. Coral reefs faced a difficult year starting 2-3 years ago. In a recent study, it was found that a third of the coral reef died in some areas of the Great Barrier Reef. This is one example of the consequences of climate change.

In last March, there was an accident in Raja Ampat Islands, Indonesia. The MV Caledonian Sky[8] - a cruise ship from Bahama sailed around the Raja Ampat area to enjoy the sea view, animals and performing arts. On the way back, MV Caledonian Sky crashed on the reef in the Raja Ampat waters. This news was quite shocking for Indonesia because Raja Ampat is known for the beauty of its marine life. The vessel damaged the coral reef in Raja Ampat and caused the fish that used to often gather to no longer be visible. Until now, this case was still unclear. But the Indonesian government has sent several people to assess the 
damage to get to know how much compensation will be sued for by Indonesia. Indonesia hopes that the owner of the ship or the Bahamas government will cooperate. However, if they do not want to pay compensation, then the Indonesian government will bring this case to court.

\section{B. Due to Damage to the Influential Coral Reefs on Climate Change}

Climate change and coral reefs are linked because climate change can threat the coral reef ecosystems. If coral ecosystems are damaged or dead, then it will cause climate change. Here is an overview of the relationship between the coral reef and climate change:

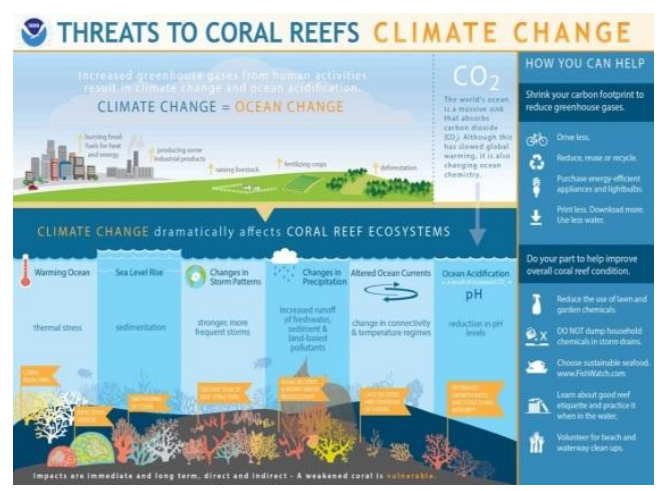

Figure 1. Source :

https://oceanservice.noaa.gov/facts/coralr eef-climate.html

Global warming or climate change has a dramatic impact on coral reef ecosystems and other marine biota. Climate change has a bad impact on the sea that also damages the coral reefs. The destruction of coral reefs can cause some impacts such as:
a. Warming Ocean
b. Sea Level Rise
c. Changes in Storm Patterns
d. Changes in Precipitation
e. Altered Ocean Currents
f. Ocean Acidification

Human activities continue to endanger the survival of coral reefs. Poor waste disposal and unplanned land use is one such example. In view of these threats, a management strategy is needed to save the coral reef ecosystem by creating marine protected areas, restricting coral reef fisheries, and maintaining integrated coastal management. Furthermore, there needs to be a restoration and conservation of the coral reefs.

Damage to coral reefs is not only because of polluted environments or pests, but coral reefs can also be damaged by fishing equipment used by fishermen, such as fish bombs, toxic chemicals - narcotics, trawls, etc.

\section{Regulation on Protection and Prevention of Coral Reef Degradation}

There are no regulations or treaties on coral reefs in international law. So far, international arrangements are in UNCLOS, CBD, Agenda 21, CITES, UNFCC, World Heritage Convention and ICM. There are no individual arrangements or conventions about coral reefs. There is an ICRI that is a combination of countries, organisations and other bodies to seek to preserve and protect coral reefs around the world. In addition to ICRI, there are also various conservation regulations, policies and treaties between two parties or more. There are also symposiums and conferences that are held yearly to talk about coral reefs.

Whereas in Indonesia, the regulation of coral reefs is contained in (1) local regulations in several sectors devoted to conservation, management and the protection of coral reefs and (2) ministerial regulations on conservation, protection and general guidelines. In addition, coral reefs are also regulated in law. Indonesia has several laws in some sectors which regulate some of the provisions about coral reefs. For example, there is the Law of the Republic of Indonesia Number 312004 , Law of the Republic of Indonesia No. 45 of 2009 on fisheries and Law No. 27 of 2007 Law No. 12014 on the Management of Coastal Zones and Small Islands. However, Indonesia has no specific law on coral reefs.

The efforts that have been undertaken by states around the world and the government of Indonesia are still not able to protect the coral reefs from 
degradation caused by humans. This has led to climate change and global warming is still happening to this day. Sometimes the rules have obliged parties to comply, but in fact, there are still some who violate these terms. In addition, people do not have an awareness of and knowledge about the importance of maintaining coral reef ecosystems to prevent the occurrence of climate change and global warming. Despite there being policies, regulations, laws and even sanctions, the government and law enforcement agencies are not decisive in supervising and enforcing regulations. The rule is wasted.

\section{CONCLUSIONS}

Coral reefs are one of the important ecosystems related to the sustainability of existing resources in coastal and marine areas. Currently, the community, especially fishermen, is more concerned with catching fish massively which can damage coral reefs, rather than the sustainability of resources. Despite marine conservation attempts to rescue coral reefs in an effort to reduce climate change, sanctions are uncontrolled by the Indonesian government and a lack of attention from law enforcement has led to the loosening of the regulations. Legislation related to marine conservation has not been fully implemented in the management of marine natural resources, especially coral reefs as well as the community still finding it difficult to obey the regulations. The specific provisions on marine conservation to save coral reefs have not been regulated separately.

\section{References}

[1] Tridoyo Kusumastanto, Degradasi Lingkungan Pesisir dan Laut Pada Era otonomi Daerah, dalam Proceeding Workshop;Deteksi, Mitigasi dan Pencegahan Degradasi Lingkungan Pesisir dan Laut di Indonesia, Pustaka Indo Repro, Jakarta, 2004.

[2] Prosiding Lokakarya, Perikanan Berkelanjutan dan Peranan Kawasan Konservasi laut, Kerjasama Dirjen Pesisir dan Pulau-pulau Kecil, DKP dan Direktur Jenderal Perlindungan Hutan dan
Konservasi Alam Departemen Kehutanan, dengan WWF Wallace, The Nature Concervancy(TNC), Proyek Pesisir, Natural Resources Management Program(NRM), Jakarta, 2003.

[3] dan [4] Peter Mahmud Marzuki, Penelitian Hukum, Kencana Prenada Media Group, Jakarta, 2005.

[5] Justin Worland, Coral Reef Conditions Are About to Get a Lot Worse, Time News, 2017. Diakses pada 13 Maret 2017.

[6] Bernike Hendrastuti, Pemutihan Terumbu Karang, Parang Tritis Geomaritime Science Park, 2017. Diakses pada 27 Maret 2017.

[7] Deddy S., Menakar Kondisi Terkini Terumbu Karang di Indonesia, CNN Indonesia - Student, 2017. Di akses pada 3 April 2017.

[8] Triono Wahyu Sudibyo, Perusakan Karang Raja Ampat - Kapten Kapal Gegabah, ini Kronologi Hancurnya di Raja Ampat, Detik News, 2017. Diakses pada 30 April 2017. 